\title{
A proposal for the unification of five species of the cyanobacterial genus Microcystis Kützing ex Lemmermann 1907 under the Rules of the Bacteriological Code
}

\author{
1,2 Department of Applied \\ Biological Chemistry ${ }^{1}$ and \\ Global Agricultural \\ Science ${ }^{2}$, Graduate \\ School of Agricultural \\ and Life Sciences, The \\ University of Tokyo, \\ Yayoi, Bunkyo-ku, \\ Tokyo 113-8657, Japan \\ 3,4 Global Environmental \\ Forum $^{3}$ and National \\ Institute for \\ Environmental Studies 4 , \\ 16-2 Onogawa, Tsukuba, \\ Ibaraki 305-0053, Japan
}

\author{
Shigeto Otsuka, ${ }^{1}$ Shoichiro Suda, ${ }^{3}+$ Satoshi Shibata, ${ }^{1}$ Hiroshi Oyaizu, ${ }^{2}$ \\ Satoshi Matsumoto ${ }^{1}$ and Makoto M. Watanabe ${ }^{4}$ \\ Author for correspondence: Shigeto Otsuka. Tel: +8135841 5140. Fax: +8135841 8042. \\ e-mail: shigeton@mac.com
}

\begin{abstract}
Genomic DNA homologies were examined from six Microcystis (cyanobacteria) strains, including five different species, Microcystis aeruginosa, Microcystis ichthyoblabe, Microcystis novacekii, Microcystis viridis and Microcystis wesenbergii. All DNA-DNA reassociation values between two strains of $M$. aeruginosa and the other four species exceeded $70 \%$, which is considered high enough for them to be classified within the same bacterial species. It is proposed to unify these five species into $M$. aeruginosa under the Rules of the Bacteriological Code and NIES843' ( = IAM M-247') is proposed as the type strain. Two other species, Microcystis flos-aquae and Microcystis pseudofilamentosa, should be regarded as morphological variations of this unified $M$. aeruginosa. The current taxonomy of cyanobacteria depends too much upon morphological characteristics and must be reviewed by means of bacteriological methods as well as traditional botanical methods.
\end{abstract}

Keywords: cyanobacteria, DNA-DNA hybridization, Microcystis, taxonomy, unification

\section{INTRODUCTION}

The blue-green algae, or cyanobacteria, have traditionally been classified on the basis of morphological and physiological characteristics and described under the rules of the Botanical Code. However, $16 \mathrm{~S}$ and $5 \mathrm{~S}$ rDNA sequence data placed this phylum within the Bacteria (Woese, 1987) which was supported by many other authors (e.g. Gupta, 1998). Describing this group in the same manner as most other bacteria is accompanied by the problem that existing genera and species have been described based solely on morphological characteristics observed in field samples (Castenholz \& Waterbury, 1989). This problem has to date hindered the classification of cyanobacteria under the Bacteriological Code.

The colonial cyanobacterium Microcystis is a plank-

†Present address: Microbial Diversity Group, Kamaishi Laboratories, Marine Biotechnology Institute, Heita, Kamaishi, Iwate 026-0001, Japan.

The DDBJ/EMBL/GenBank accession numbers for the 16S rDNA sequences of Microcystis strains used in this study are listed in Fig. 1. tonic and toxigenic organism that usually occurs in eutrophic lakes, ponds and reservoirs and often forms water blooms from summer to late autumn (Carmichael, 1996). Delimitation and validity of Microcystis species have been discussed in a number of papers. Twenty-three Microcystis species were described by Geitler (1932), which included species both with and without gas vesicles. Stanier et al. (1971) suggested that only cells containing gas vesicles should be considered as Microcystis. According to the most recent edition of Bergey's Manual of Determinative Bacteriology (Holt et al., 1994), Microcystis is characterized as having gas vesicles, a coccoid cell shape, a tendency to form aggregates or colonies, and an amorphous mucilage or a sheath. It must be noted, however, that gas vesicles are sometimes lost during subculture. Incidentally, some authors describe gas vacuoles (an assemblage of numerous gas vesicles) as aerotopes (Komárek \& Anagnostidis, 1998). As species which meet these criteria, Watanabe (1996) recently distinguished five species in Japanese waters: Microcystis aeruginosa (Kützing) Kützing 1846, Microcystis ichthyoblabe Kützing 1843, Microcystis novacekii 
(Komárek) Compère 1974, Microcystis viridis (A. Braun) Lemmermann 1903 emend. Kondrateva 1975 and Microcystis wesenbergii (Komárek) Komárek in Kondrateva 1968. In addition to these five species, Komárek (1991) distinguished Microcystis flos-aquae (Wittrock) Kirchner 1898, while Watanabe (1996) regarded this as one type of $M$. ichthyoblabe. In some cases, M. ichthyoblabe (including M. flos-aquae) and $M$. novacekii are not distinguished from $M$. aeruginosa (e.g. Kato et al., 1991). It must be noted that although 'M. aeruginosa (Kützing) Lemmermann 1907' is the correct type species name of Microcystis according to the last edition of Nomina Conservanda, the name $M$. aeruginosa (Kützing) Kützing 1846 is used by many authors (e.g. Watanabe, 1996; Komárek \& Anagnostidis, 1998). The interpretation by Komárek (1957) is helpful to comprehend this nomenclatural problem. Although the genus name Microcystis Kützing 1833 was invalid according to the first diagnoses, Kützing himself used the name $M$. aeruginosa for the present $M$. aeruginosa in his publications in 1846 and later (Komárek, 1957). This is the reason why the name $M$. aeruginosa (Kützing) Kützing 1846 is accepted by many authors.

In all of these studies, it was primarily cell size, colonial form and sheath characteristics that were used as the taxonomic criteria, and the term 'morphospecies' was given to this classification of Microcystis species. Colonies of Microcystis, however, can easily change in form or disaggregate during serial subculture and it becomes difficult to re-identify them. Several attempts have been made to define taxonomic criteria, other than morphological ones, for cultured and disaggregated Microcystis cells. Fahrenkrug et al. (1992) examined DNA base composition of a number of cyanobacteria, including four Microcystis strains. The Microcystis strains used in this study had fairly similar base compositions, $38-43 \mathrm{~mol} \% \mathrm{G}+\mathrm{C}$, which was confirmed (39-43 mol\% $\mathrm{G}+\mathrm{C}$ ) by Otsuka et al. (1999b). Krüger et al. (1995) investigated the fatty acid composition of Microcystis species as a taxonomic criterion and concluded that this attribute may be particularly helpful in cyanobacterial taxonomy, including the genus Microcystis. However, their investigation was not performed in relation to species delimitation and Otsuka et al. (1999b) reported that the fatty acid composition of Microcystis morphospecies was irrelevant to species distinction. Neilan et al. (1997) and Otsuka et al. (1998) presented phylogenetic trees of strains in the genus Microcystis based on $16 \mathrm{~S}$ rDNA sequence comparisons. These trees did not reflect the classification based on morphological characteristics and Otsuka et al. (1998) concluded that the five Microcystis morphospecies investigated may possibly be unified into one species. This idea was partially supported by Kondo et al. (2000) with the result of DNA-DNA hybridization tests using three Microcystis morphospecies. Cell size, growth temperature range, salinity tolerance, restriction fragment length polymorphism on PCR amplification products
(PCR-RFLP) of the $c p c B A$ intergenic spacer and flanking region (IGS), and a phylogenetic analysis based on $16 \mathrm{~S}-23 \mathrm{~S}$ internal transcribed spacer (ITS) sequence comparisons also failed to support the validity of the current taxonomy of Microcystis (Neilan et al., 1995; Bolch et al., 1996; Otsuka et al., 1999a, b).

In this paper we report the genomic DNA homologies among six strains, including five Microcystis morphospecies, and reconsider the current classification of Microcystis species according to bacteriological taxonomic criteria.

\section{Methods}

Strains. Six strains, including five morphospecies used in the hybridization study are listed in Table 1. Throughout our study, M. flos-aquae is not distinguished from M. ichthyoblabe, according to Watanabe (1996). The five strains other than TAC86 were isolated from 1996 to 1997 and their morphospecies-characteristic colonial forms have been recorded photographically to certify the correct identification of these strains (Otsuka et al., 2000). M. aeruginosa strain NIES843 ${ }^{\mathrm{T}}\left(=\mathrm{IAM} \mathrm{M}-247^{\mathrm{T}}\right)$ was previously designated $M$. aeruginosa strain NC7 (Otsuka et al., 2000). The strains were purified and cloned by the micropipette-washing method. Purity of the strains was checked by bacterial check media (Watanabe \& Hiroki, 1997) and fluorescent microscopy with DAPI staining. Cultures were maintained in MA medium (Ichimura, 1979) at $20^{\circ} \mathrm{C}$ under a $12: 12 \mathrm{~h}$ light/dark cycle with a photon flux density of about $30 \mu \mathrm{mol} \mathrm{m}{ }^{-2} \mathrm{~s}^{-1}$ provided by daylight fluorescent lamps.

Sequencing and phylogenetic analysis. The 16S rDNA sequence of $M$. aeruginosa TAC 86 had been determined previously (Otsuka et al., 1998) and the sequences of other five strains were determined in this study. DNA for use in PCR was extracted according to Palinska et al. (1996) with minor modifications. PCR amplification and sequencing were also carried out as described previously (Otsuka et al., 1998). The sequence alignment, including the six strains under examination here as well as 10 other strains of Microcystis, other cyanobacteria and related organisms, was obtained using the multiple sequence alignment tools in CLUSTAL x (Thompson et al., 1997), then converted to a distance matrix. The distance matrix was used to reconstruct a phylogenetic tree using the neighbour-joining algorithm of CLUSTAL $\mathrm{x}$, with multiple substitutions corrected and positions with gaps excluded, and the seed number for random number generation and numbers of bootstrap trials were set to 111 and 1000 , respectively.

Preparation of DNA for DNA-DNA hybridizations. A $30 \mathrm{ml}$ aliquot of culture was centrifuged at $5000 \mathrm{~g}$ for $10 \mathrm{~min}$ at $4{ }^{\circ} \mathrm{C}$. The pellet was broken with a beadbeater (4600 r.p.m., $30 \mathrm{~s} \times 2)$ and resuspended in $10 \mathrm{mM}$ Tris $/ \mathrm{HCl}$ buffer (pH 8.0) containing 1 mM EDTA. One-tenth vols $10 \%$ SDS solution was added to the suspension and mixed well. The lysate was extracted at least twice with Tris-buffered phenol and at least three times with chloroform. DNA was precipitated by addition of 0.1 vols $3 \mathrm{M}$ sodium acetate and 2.5 vols ethanol. Enzyme hydrolysis of RNA was achieved by treatment with Ribonuclease T1 (Sigma-Aldrich) and ribonuclease A (Sigma-Aldrich).

DNA-DNA hybridizations. DNA-DNA hybridization experiments were performed with DNA from both $M$. aeruginosa strains as probes. Percentages of DNA reassociation were 
Table 1. Strains used in DNA-DNA hybridization experiments

\begin{tabular}{|c|c|c|c|}
\hline Morphospecies & Strain* & Geographic origin & 16S rDNA sequence reference \\
\hline M. aeruginosa & 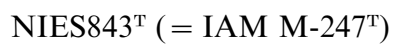 & Japan & This study \\
\hline M. aeruginosa & TAC86 & Japan & Otsuka et al. (1998) \\
\hline M. ichthyoblabe & TC24 & Thailand & This study \\
\hline M. novacekii & $\mathrm{BC} 18$ & United Kingdom & This study \\
\hline M. viridis & CC9 & Peoples Republic of China & This study \\
\hline M. wesenbergii & TC7 & Thailand & This study \\
\hline
\end{tabular}

* IAM, Institute of Molecular and Cellular Biosciences Culture Collection, The University of Tokyo, Tokyo, Japan; NIES, National Institute for Environmental Studies Collection, Tsukuba, Japan; TAC, Tsukuba Algal Collection, National Science Museum, Tsukuba, Japan.

determined fluorometrically from the extent of hybridization by the method of Ezaki et al. (1989). The optimal renaturation temperature, calculated from the $\mathrm{G}+\mathrm{C}$ content (Fahrenkrug et al., 1992; Holt et al., 1994; Otsuka et al., 1999b), was approximately $31^{\circ} \mathrm{C}$, which is $55^{\circ} \mathrm{C}$ lower than the $T_{\mathrm{m}}$ according to Meinkoth \& Wahl (1984) and Ezaki et al. (1989), and a concentration of $100 \mu \mathrm{g}$ DNA ml ${ }^{-1}$ was used. Each experiment was repeated at least five times.

\section{RESULTS AND DISCUSSION}

The taxonomic relationships between the Microcystis morphospecies are uncertain. Recently published data based on physiological and biochemical characteristics, PCR-RFLP of the $c p c B A$ IGS, 16S rDNA and $16 \mathrm{~S}-23 \mathrm{~S}$ ITS sequences strongly indicated that the current morphological classification of the Microcystis species is invalid (Neilan et al., 1997; Otsuka et al., 1998, 1999a, b). The lengths of the 16S rDNAs of the present six strains were identical, $1457 \mathrm{bp}$, between positions 33 and 1542 of the 16S rDNA of Escherichia coli. Similar to the results of Otsuka et al. (1998), all six strains had high sequence similarity, exceeding $99.5 \%$

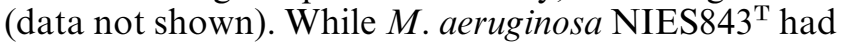
$100 \%$ sequence similarity with $M$. viridis CC9, it had $99.5 \%$ sequence similarity to $M$. aeruginosa TAC86, currently classified as the same morphospecies. Thus the six strains are closely related to one another, regardless of species distinction. In the Microcystis cluster of the neighbour-joining tree based on $16 \mathrm{~S}$ rDNA sequences (Fig. 1), there is no clear division

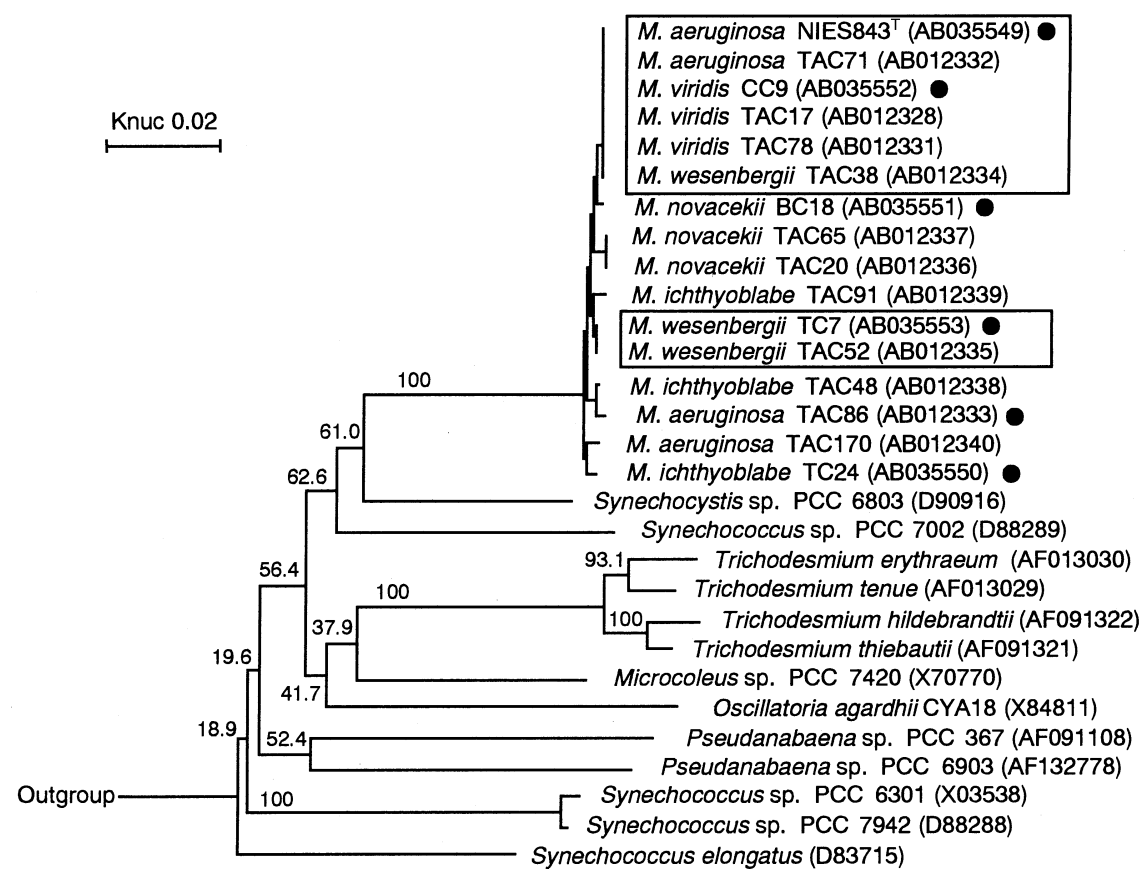

Fig. 1. Neighbour-joining tree of the Microcystis strains and related organisms. An alignment of $1347 \mathrm{nt}$ after excluding positions with gaps was used. Local bootstrap probabilities (for branches except those within the Microcystis cluster) are indicated at nodes. Strains marked with a black circle were used for DNA-DNA hybridization and strains in each rectangle have an identical sequence. Accession numbers in the DDBJ/EMBL/GenBank databases are indicated in parentheses. $E$. coli (accession no. E05133), used as an outgroup, is not shown. 
Table 2. Genomic DNA homologies (\%) between each Microcystis strain and two strains of $M$. aeruginosa used in DNA-DNA hybridization experiments

\begin{tabular}{|c|c|c|c|c|c|c|}
\hline Probe & $\begin{array}{l}\text { M. aeruginosa } \\
\text { NIES843 }^{\mathrm{T}}\end{array}$ & $\begin{array}{l}\text { M. aeruginosa } \\
\text { TAC86 }\end{array}$ & $\begin{array}{l}\text { M. ichthyoblabe } \\
\text { TC24 }\end{array}$ & $\begin{array}{l}\text { M. novacekii } \\
\text { BC18 }\end{array}$ & $\begin{array}{l}\text { M. viridis } \\
\text { CC9 }\end{array}$ & $\begin{array}{c}\text { M. wesenbergit } \\
\text { TC7 }\end{array}$ \\
\hline $\begin{array}{l}\text { M. aeruginosa } \\
{\text { NIES } 843^{\mathrm{T}}}\end{array}$ & 100 & $74 \cdot 1$ & $80 \cdot 7$ & $74 \cdot 0$ & $91 \cdot 7$ & $89 \cdot 7$ \\
\hline $\begin{array}{l}\text { M. aeruginosa } \\
\text { TAC } 86\end{array}$ & $75 \cdot 0$ & 100 & $86 \cdot 4$ & $85 \cdot 2$ & 75.9 & $74 \cdot 6$ \\
\hline
\end{tabular}

which agrees with the current species classification. Compared with the cluster of Trichodesmium spp. or Pseudanabaena spp., 16S rDNA differentiation within the genus Microcystis is low. DNA-DNA binding percentages were all greater than $70 \%$ (Table 2). While the percentage hybridization between the two strains of $M$. aeruginosa, NIES $843^{\mathrm{T}}$ and TAC86, was $74 \cdot 1-$ $75.0 \%$, that between $M$. aeruginosa NIES $843^{\mathrm{T}}$ and $M$. viridis CC9 was $91.7 \%$, despite the fact that these two strains have been classified as different morphospecies. As with the 16S rDNA similarities, the genomic DNA homologies did not correspond with the current species classification. It is considered that the relative binding percentage should be higher than $70 \%$ within a bacterial species (Wayne et al., 1987). According to this criterion the present six strains can be classified as members of the same species.

Microcystis spp. classification has traditionally been chiefly based on morphological characteristics. There is a problem, however, in the application of morphological criteria to cyanobacterial classification because of the variability of characteristics in response to changes in the environment (Dor \& Hornhoff, 1985). Palinska et al. (1996) showed that the great morphological diversity observed in nature and (partially) in culture does not necessarily reflect genetic diversity and mentioned the likelihood that more 'ecophenic' and/or phenotypic forms have been described rather than genotypic species. Otsuka et al. (2000) showed that Microcystis strains can change their colonial forms in culture and, as a result, the morphological characteristics of many morphospecies overlap. Microcystis spp. possibly change colony forms in the field as well as in culture, which is thought to have caused uncertainty in the present classification of Microcystis species. It has been suggested that genetic data must be taken into consideration for classification of Microcystis species. The difference in colonial form must be regarded as intraspecific or phenotypic variation. Kato et al. (1991) concluded that $M$. viridis and M. wesenbergii are both well-established species based on allozyme tests. This, however, was not supported by Otsuka et al. (1999a, b). Additionally, Kato et al. (1991) did not illustrate the validity of using genotypes derived from allozyme tests for species-level classification. The differences in the genotype can also be regarded as intraspecific variation.

In this study, we propose the unification of the five (or more) morphospecies of the genus Microcystis. This unification is necessary since even a single strain sometimes has characteristics corresponding to more than two morphospecies or an intermediate form between two or more morphospecies (Otsuka et al. 2000). For valid publication of cyanobacterial names and type strains under the Rules of Bacteriological Code, the following points are important.

1. New names or combinations must be published in the International Journal of Systematic and Evolutionary Microbiology (IJSEM) and if published elsewhere, the new names or combinations are not validly published until they are published in IJSEM.

2. The Botanical Code specifies that names of Cyanophyta validly published under the Bacteriological Code as cyanobacteria are valid according to the Botanical Code and the International Committee on Systematic Bacteriology (ICSB) in 1986 approved that names of cyanobacteria described and validly published as bluegreen algae under the International Code of Botanical Nomenclature (ICBN) are recognized as having been validly published under the International Code of Nomenclature of Bacteria (ICNB) (see Castenholz \& Waterbury, 1989).

3. A proposal of neotype strains for consideration by the Judicial Commission of the ICSB must be published in the IJSEM.

Although none of the Microcystis morphospecies meet the criteria in point 1 above, each name must be regarded as valid under the ICNB, according to point 2. Since $M$. aeruginosa is the type species of this genus under the ICBN, this is the most suitable species name for the unified species. Microcystis morphospecies have to date had no valid type strain. In the strain catalogue of Pasteur Culture Collection (Rippka \& Herdman, 1992), M. aeruginosa PCC 7941 was proposed as the type strain, but this proposal was not made under the Rules of the Bacteriological Code (see point 3). The origin of strain PCC 7941 was strain NRC-1, which was isolated in the study of Hughes et al. (1958). However, the authors failed to describe morphological characteristics from which they used to identify the strain as M. aeruginosa and for this reason strain PCC 7941 is not a suitable type strain. We propose $M$. aeruginosa NIES $843^{\mathrm{T}}$ (= IAM M-247 ${ }^{\mathrm{T}}$ ) as the type strain of the unified $M$. aeruginosa. Since the correct identification of Microcystis morphospecies is some- 
times in doubt, we selected strains whose characteristics are well documented (cf. Otsuka et al., 2000) and did not include strain PCC 7941 in the present study. Incidentally, the 16S rDNA sequence of strain PCC 7941 (accession no. AJ133171) has 99.4\% similarity to that of $M$. aeruginosa NIES843 ${ }^{\mathrm{T}}$ (data not shown).

M. flos-aquae and Microcystis pseudofilamentosa Crow 1923 should be included in the unified $M$. aeruginosa, since the colonial characteristics of these two species were shown to be morphological variations of one or more of the five morphospecies (Otsuka et al., 2000). In addition, Kondo et al. (2000) reported that DNADNA relative binding percentages between a strain of M. flos-aquae [M. aeruginosa (Kützing) Lemmermann f. flos-aquae (Wittrock) Elenkin 1938 in their study] and strains of $M$. aeruginosa, $M$. viridis and $M$. wesenbergii were greater than $70 \%$. An intermediate colonial form between Microcystis botrys Teiling 1942 and $M$. novacekii was observed during our study (data not shown) and partial sequences of 16S rDNA (478 bp) of $M$. botrys strains NIVA-CYA 161/1 and NIVA-CYA 264 (accession nos Y12608 and Y12609, respectively) have $100 \%$ similarity with that of $M$. aeruginosa NIES $843^{\mathrm{T}}$. These facts indicate the possibility that $M$. botrys could also be included in the unified M. aeruginosa. Microcystis elabens Kützing 1846, Microcystis holsatica Lemmermann 1907 and Microcystis incerta (Lemmermann) Lemmermann 1907 have sometimes been described in recent papers (e.g. Neilan et al., 1997). However, M. holsatica and M. incerta always lack gas vesicles. M. elabens NIES42 and $M$. holsatica NIES43 were shown to be phylogenetically distant from the major Microcystis cluster, but clustered with Synechococcus sp. PCC 6301 (Neilan et al., 1997). In addition, M. elabens has rod-shaped cells. These facts indicate that these morphospecies should not be included in Microcystis. Komárek \& Anagnostidis (1998) described a number of Microcystis morphospecies in their recent revision of Chroococcales cyanobacteria (including 10 as species in Europe, 11 as species outside Europe and some other "unrevised taxa'). They suspected that some of the morphospecies were synonyms of other Microcystis or should be moved to other genera. Besides these 'suspected' morphospecies and those proposed to be unified in this study, there are still eight to ten other morphospecies in their revision. Among these morphospecies, diagnostic characteristics of Microcystis firma (Kützing) Schmidle 1902, Microcystis natans Lemmermann ex Skuja 1934 and Microcystis smithii Komárek et Anagnostidis 1995 were well documented and seem not to fit within the variations of the unified $M$. aeruginosa summarized in the description below (cf. Otsuka et al., 2000). The cell sizes of $M$. natans and $M$. firma are much smaller than the unified $M$. aeruginosa and $M$. smithii usually has a solitary aerotope (Komárek \& Anagnostidis, 1998).

Among strains currently classified as any of the five morphospecies (or seven, including M. flos-aquae and
M. pseudofilamentosa), there may or may not be some strains which cannot be included in the unified $M$. aeruginosa. These strains would need to be distinguished from the unified $M$. aeruginosa and classified, where appropriate, using genetic, biochemical, physiological and invariable morphological characteristics.

Morphological characteristics can give important information about the organism of interest; however, it is necessary to bear in mind that there are organisms which cannot be classified solely by morphological characteristics. The current taxonomy of cyanobacteria depends too much upon morphological characteristics and must be reviewed by means of bacteriological methods as well as traditional botanical methods. Molecular investigations, especially those based on 16S rDNA and DNA-DNA hybridization, would bring unification or division to some species, genera and even taxa of higher rank. There remain many cyanobacteria to be reconsidered regarding their taxonomy. The genus Synechococcus is an example; genetic distances among Synechococcus spp. in the neighbour-joining tree (Fig. 1) seem too large for them to be classified in a single genus and it has been shown that this is another example of an unnatural taxon (Honda et al., 1999).

\section{Description of Microcystis aeruginosa comb. nov. Kützing 1833}

Microcystis aeruginosa (ae.ru.gi.no'sa. L. fem. adj. aeruginosa full of copper rust or verdigris, hence green).

The description is based on the data from Geitler (1932), Waterbury \& Rippka (1989), Komárek (1991), Fahrenkrug et al. (1992), Holt et al. (1994), Krüger et al. (1995), Watanabe (1996) and Otsuka et al. (1999a, b, 2000). Under the Botanical Code, the species has been described as $M$. aeruginosa (Kützing) Lemmermann 1907 [=M. aeruginosa (Kützing) Kützing 1846, formerly 'Micraloa aeruginosa' Kützing 1833], M. ichthyoblabe Kützing 1843, M. novacekii (Komárek) Compère 1974 (formerly 'Diplocystis novacekii' Komárek 1958), M. viridis (A. Braun) Lemmermann 1903 emend. Kondrateva 1975 [formerly 'Polycystis viridis' A. Braun in Rabenhorst 1862, 'Diplocystis viridis' (A. Braun in Rabenhorst 1862) Komárek 1958], M. wesenbergii (Komárek) Komárek in Kondrateva 1968 (formerly 'Diplocystis wesenbergii' Komárek 1958), M. flos-aquae (Wittrock) Kirchner 1898 and M. pseudofilamentosa Crow 1923. The $\mathrm{G}+\mathrm{C}$ content of the DNA is $38-45 \mathrm{~mol} \%$ (type strain $\mathrm{G}+\mathrm{C}$ content is $41 \mathrm{~mol} \%$ ). Fatty acid composition is tetradecanoic acid, hexadecanoic acid, $\Delta 9$ hexadecenoic acid, octadecanoic acid, $\Delta 9$-octadecenoic acid, $\Delta 9,12-$ octadecadienoic acid, $\Delta 9,12,15-$ octadecatrienoic acid, $\Delta 6,9,12$-octadecatrienoic acid and $\Delta 6,9,12,15$-octadecatetraenoic acid. Hexadecanoic acid is the main component, which ranges from about 40 to $70 \%$. Cells are coccoid, $2 \cdot 5-7 \cdot 6 \mu \mathrm{m}$ in 
diameter and tend to form aggregates or colonies, with amorphous mucilage or a sheath. Morphological characteristics of the colony vary as follows: (1) more or less firm, elongated or lobated usually with distinct holes, subspherical and reticulated, and the margin of the colonial envelope is invisible under a microscope without treatment (colony type 1); (2) soft, the distribution of cells in colonies is homogeneous, irregular or sponge-like, and the margin of the colony is irregular and invisible under a microscope without treatment (colony type 2); (3) small and firm, not lobated, composed of tightly aggregated cells and a thick surrounding gelatinous substance, sometimes elongate discontinuously (colony type 3); (4) firm, small and composed of cubic subcolonies that contain eight cells and the margin of colonies is usually visible, undulating in natural populations (colony type 4); (5) spherical, elongated, lobated, with visible margin, limited by smooth, continual, refractive line and filled with mucilage, with cells arranged in a single layer inside the margin or aggregated in the centre of the colony (colony type 5$) ;(6)$ intermediate form between any two or more types; and (7) other forms corresponding to none of the above types 1-5 (cf. Otsuka et al., 2000). The colonies can easily change in form or disaggregate during serial subculture. The cell usually has gas vesicles which are sometimes lost. Some strains produce the cyclic heptapeptide hepatotoxin, microcystin (type strain is positive for this). Type strain is $\operatorname{NIES} 843^{\mathrm{T}}\left(=\right.$ IAM M-247 $\left.{ }^{\mathrm{T}}\right)$.

\section{ACKNOWLEDGEMENTS}

We are very grateful to Dr Akira Yokota, The University of Tokyo, Japan, for valuable advice on bacteriological taxonomy; Dr Masayuki Watanabe, National Science Museum, Japan, Dr Jirí Komárek, Czech Republic, and Dr Hisayoshi Nozaki, The University of Tokyo, Japan, for their helpful information on botanical nomenclature of the genus Microcystis. We also thank Dr Bronwyn Robertson, National Institute for Environmental Studies, Japan, for revision of the English text. This work was supported by the Science and Technology Agency, Japan.

\section{REFERENCES}

Bolch, C. J. S., Blackburn, S. I., Neilan, B. A. \& Grewe, P. M. (1996). Genetic characterization of strains of cyanobacteria using PCRRFLP of the $c p c B A$ intergenic spacer and flanking regions. $J$ Phycol 32, 445-451.

Carmichael, W. W. (1996). Toxic Microcystis and the environment. In Toxic Microcystis, pp. 1-11. Edited by M. F. Watanabe, K. Harada, W. W. Carmichael \& H. Fujiki. Boca Raton: CRC Press.

Castenholz, R. W. \& Waterbury, J. B. (1989). Group I. Cyanobacteria. Preface. In Bergey's Manual of Systematic Bacteriology, vol. 3, pp. 1710-1727. Edited by J. T. Staley, M. P. Bryant, N. Pfennig \& J. G. Holt. Baltimore: Williams \& Wilkins.

Dor, I. \& Hornhoff, M. (1985). Salinity-temperature relations and morphotypes of mixed population of coccoid cyanobacteria from a hot, hypersaline pond in Israel. Mar Ecol 6, 13-25.
Ezaki, T., Hashimoto, Y. \& Yabuuchi, E. (1989). Fluorometric deoxyribonucleic acid-deoxyribonucleic acid hybridization in microdilution wells as an alternative to membrane filter hybridization in which radioisotopes are used to determine genetic relatedness among bacterial strains. Int J Syst Bacteriol 39, 224-229.

Fahrenkrug, P. M., Bett, M. B. \& Parker, D. L. (1992). Base composition of DNA from selected strains of the cyanobacterial genus Microcystis. Int J Syst Bacteriol 42, 182-184.

Geitler, L. (1932). Cyanophyceae. In Kryptogramenflora von Deutschland, Österreich und der Schweiz, vol. 14, pp. 130-148. Edited by L. Rabenhorst. Leipzig: Akademische Verlagsgesellschaft.

Gupta, R. S. (1998). Protein phylogenies and signature sequences: a reappraisal of evolutionary relationships among archaebacteria, eubacteria, and eukaryotes. Microbiol Mol Biol Rev 62, 1435-1491.

Holt, J. G., Krieg, N. R., Sneath, P. H. A., Staley, J. T. \& Williams, S. T. (1994). Group 11. Oxygenic phototrophic bacteria. In Bergey's Manual of Determinative Bacteriology, 9th edn, pp. 377-425. Edited by W. R. Hensyl. Baltimore: Williams \& Wilkins.

Honda, D., Yokota, A. \& Sugiyama, J. (1999). Detection of seven major evolutionary lineages in cyanobacteria based on the $16 \mathrm{~S}$ rRNA gene sequence analysis with new sequences of five marine Synechococcus strains. J Mol Evol 48, 723-739.

Hughes, E. O., Gorham, P. R. \& Zehnder, A. (1958). Toxicity of a unialgal culture of Microcystis aeruginosa. Can J Microbiol 4, 225-236.

Ichimura, T. (1979). 2. Isolation and culture methods of algae (2. Sôrui no bunri to baiyôhô. 2.5.B. Tansui sôrui) (in Japanese without English title). In Methods in Phycological Studies (Sôrui Kenkyûhô), pp. 294-305. Edited by K. Nishizawa \& M. Chihara. Tokyo: Kyoritu Shuppan.

Kato, T., Watanabe, M. F. \& Watanabe, M. (1991). Allozyme divergence in Microcystis (Cyanophyceae) and its taxonomic inference. Arch Hydrobiol Suppl Algol Stud 64, 129-140.

Komárek, J. (1957). Das 'Microcystis'-Problem. Taxon 6, 145-149.

Komárek, J. (1991). A review of water-bloom forming Microcystis species, with regard to populations from Japan. Arch Hydrobiol Suppl Algol Stud 64, 115-127.

Komárek, J. \& Anagnostidis, K. (1998). Band 19 - Cyanoprokaryota. 1. Teil Chroococcales. In Süsswasserflora von Mitteleuropa, pp. 225-236. Edited by H. Ettl, G. Gärtner, H. Heynig \& D. Mollenhauer. Jena: Gustav Fischer Verlag.

Kondo, R., Yoshida, T., Yuki, Y. \& Hiroishi, S. (2000). DNA-DNA reassociation among a bloom-forming cyanobacterial genus, Microcystis. Int J Syst Evol Microbiol 50, 767-770.

Krüger, G. H. J., De Wet, H., Kock, J. L. F. \& Pieterse, A. J. H. (1995). Fatty acid composition as a taxonomic characteristic for Microcystis and other coccoid cyanobacteria (blue-green alga) isolates. Hydrobiologia 308, 145-151.

Kützing, F. T. (1845-1849). Tabulae Phycologicae oder Abbildungen der Tange I.

Meinkoth, J. \& Wahl, G. (1984). Hybridization of nucleic acids immobilized on solid supports. Anal Chem 138, 267-284.

Neilan, B. A., Jacobs, D. \& Goodman, A. E. (1995). Genetic diversity and phylogeny of toxic cyanobacteria determined by DNA polymorphisms within the phycocyanin locus. Appl Environ Microbiol 61, 3875-3883.

Neilan, B. A., Jacobs, D., Del Dot, T., Blackall, L. L., Hawkins, P. R., 
Cox, P. T. \& Goodman, A. E. (1997). rRNA sequences and evolutionary relationships among toxic and nontoxic cyanobacteria of the genus Microcystis. Int J Syst Bacteriol 47, 693-697.

Otsuka, S., Suda, S., Li, R., Watanabe, M., Oyaizu, H., Matsumoto, S. \& Watanabe, M. M. (1998). 16S rDNA sequences and phylogenetic analyses of Microcystis strains with and without phycoerythrin. FEMS Microbiol Lett 164, 119-124.

Otsuka, S., Suda, S., Li, R., Watanabe, M., Oyaizu, H., Matsumoto, S. \& Watanabe, M. M. (1999a). Phylogenetic relationships between toxic and nontoxic strains of the genus Microcystis based on $16 \mathrm{~S}$ to $23 \mathrm{~S}$ internal transcribed spacer sequence. FEMS Microbiol Lett 172, 15-21.

Otsuka, S., Suda, S., Li, R., Watanabe, M., Oyaizu, H., Matsumoto, S. \& Watanabe, M. M. (1999b). Characterization of morphospecies and strains of the genus Microcystis (cyanobacteria) for a reconsideration of species classification. Phycol Res 47, 189-197.

Otsuka, S., Suda, S., Li, R., Matsumoto, S. \& Watanabe, M. M. (2000). Morphological variability of colonies of Microcystis morphospecies in culture. J Gen Appl Microbiol 46, 57-68.

Palinska, K. A., Liesack, W., Rhiel, E. \& Krumbein, W. E. (1996). Phenotype variability of identical genotypes: the need for a combined approach in cyanobacterial taxonomy demonstrated on Merismopedia-like isolates. Arch Microbiol 166, 224-233.

Rippka, R. \& Herdman, M. (1992). Part 4: strain list. In Pasteur Culture Collection of Cyanobacteria, Catalogue \& Taxonomic Handbook, Volume I: Catalogue of Strains (1992/1993), pp.
12-59. Edited by R. Rippka \& M. Herdman. Paris: Institut Pasteur.

Stanier, R. Y., Kunisawa, R., Mandel, M. \& Cohen-Bazire, G. (1971). Purification and properties of unicellular blue-green algae (order Chroococcales). Bacteriol Rev 35, 171-205.

Thompson, J. D., Gibson, T. J., Plewniak, F., Jeanmougin, F. \& Higgins, D. G. (1997). The CLUSTAL X windows interface: flexible strategies for multiple sequence alignment aided by quality analysis tools. Nucleic Acids Res 24, 4876-4882.

Watanabe, M. (1996). Isolation, cultivation, and classification of bloom-forming Microcystis in Japan. In Toxic Microcystis, pp. 13-34. Edited by M. F. Watanabe, K. Harada, W. W. Carmichael \& H. Fujiki. Boca Raton: CRC Press.

Watanabe, M. M. \& Hiroki, M. (1997). VI. Media. In NIES Collection. List of Strains, Algae and Protozoa, 5th edn, pp. 30-38. Edited by M. M. Watanabe \& M. Hiroki. Ibaraki, Japan: National Institute for Environmental Studies.

Waterbury, J. B. \& Rippka, R. (1989). Subsection I. Order Chroococcales Wettstein 1924, emend. Rippka et al., 1979. In Bergey's Manual of Systematic Bacteriology, vol. 3, pp. 17281746. Edited by J. T. Staley, M. P. Bryant, N. Pfennig \& J. G. Holt. Baltimore: Williams \& Wilkins.

Wayne, L. G., Brenner, D. J., Colwell, R. R. \& 9 other authors. (1987). International Committee on Systematic Bacteriology. Report of the ad hoc committee on reconciliation of approaches to bacterial systematics. Int J Syst Bacteriol 37, 463-464.

Woese, C. R. (1987). Bacterial evolution. Microbiol Rev 51, 221-271. 